So much work has now been published on cot death that, in the light of the fate of this major strand of the work in the years before the information explosion and the time needed to document medical papers thoroughly in the midst of that explosion, I suggest that an exhaustive bibliography should be published. This should be arranged chronologically under many headings' and extensively cross referenced. Such a publication would almost certainly have to be sponsored, and it would have to be updated every few years.

I thank Professor A S Douglas for helpful comment. T M ALLAN

Aberdeen University Medical Library

Aberdeen AB9 2ZD

Stewart-Brown S. Cot death and sleeping position. BMJ 1992;304:1508. (6 June.)

2 Abramson $\mathrm{H}$. Accidental mechanical suffocation in infants. 7 Pediatr 1944;25:404-13.

3 Werne J, Garrow I. Sudden deaths of infants allegedly due to mechanical suffocation. Am f Public Health 1947;37:675-87. 4 New York Academy of Medicine. Annual report. New York: New York Academy of Medicine, 1945:40

5 Prone or supine? [Editorial.] BMJ 1961;i:1304.

\section{Dispensing doctors}

EDITOR,-David Roberts has grossly misinterpreted the statistics from the Prescription Pricing Authority in his letter on dispensing doctors. ${ }^{1}$ Closer examination of the detail provided in the authority's annual report for 1990-1 shows that savings could be made if all dispensing was undertaken by pharmacists.

TABLE I-Average cost (£) of prescriptions dispensed by pharmacists and appliance contractors and dispensing doctors in England, 1990-1

\begin{tabular}{lcc}
\hline & $\begin{array}{c}\text { Pharmacists } \\
\text { and appliance } \\
\text { contractors }\end{array}$ & $\begin{array}{c}\text { Dispensing } \\
\text { doctors }\end{array}$ \\
\hline Ingredient cost & 5.865 & 5.411 \\
Discount & -0.556 & -0.365 \\
Oncost allowance & 0.302 & 0.568 \\
Fees & 1.058 & 0.893 \\
Container allowance & 0.038 & 0.038 \\
\hline & 6.697 & 6.545 \\
\hline Oxygen treatment & 0.035 & 0.002 \\
Value added tax & 0.010 & 0.775 \\
\hline Average total cost & 6.742 & 7.302 \\
\hline
\end{tabular}

Table I compares average costs of prescriptions dispensed by pharmacists and dispensing doctors in 1990-1. I agree with Roberts that value added tax should be excluded from the comparison, but so also should oxygen as, in proportion, dispensing doctors handle very little cylinder oxygen. On the face of it prescriptions dispensed by pharmacists are $15 \cdot 2 \mathrm{p}$ more expensive, but the cost of ingredients for pharmacists is $45 \cdot 4 \mathrm{p}$ higher. With the exception of generic preparations that are not listed in part VIII of the drug tariff (where the pharmacist selects the product to be dispensed and hence influences the cost of the ingredient), cost is controlled by the prescriber through the selection of the product and the quantity. The difference of $45.4 p$ is reduced by savings on discount and in remuneration-that is, oncost allowance and fees - to $15 \cdot 2 \mathrm{p}$

Table II shows the effect of applying pharmacists' costs to dispensing doctors' prescriptions. The cost of the ingredients and container allowance remain the same, fees are higher, but discount and oncost are lower. The revised average cost is $£ 6 \cdot 264$, which is $28 \cdot 1 \mathrm{p}$ less than the equivalent figure for doctors.

Thus if pharmacists had dispensed the 27014000 prescriptions dispensed by dispensing doctors in
TABLE II-Effect of applying pharmacists' costs to dispensing doctors' prescriptions

\begin{tabular}{|c|c|c|}
\hline & $£$ & \\
\hline Ingredient cost & $5 \cdot 411$ & \\
\hline Discount & -0.522 & $\begin{array}{l}(0.566 / 5.865 \text { of ingredient } \\
\text { year })\end{array}$ \\
\hline Oncost allowance & $0 \cdot 279$ & $\begin{array}{l}\text { (roughly } 5 \% \text { compared } \\
\text { with } 10 \cdot 5 \% \text { of } \\
\text { ingredient cost) }\end{array}$ \\
\hline Fees & $1 \cdot 058$ & (higher) \\
\hline Container allowance & $0 \cdot 038$ & (same) \\
\hline
\end{tabular}

$6 \cdot 264$

$1990-1 £ 7 \cdot 591 \mathrm{~m}$ would have been saved. I leave it to Roberts to calculate the potential loss had doctors dispensed all prescriptions.

GORDON L GEDDES

Assistant Secretary

Pharmaceutical Services Negotiating Committee,

Aylesbury,

Buckinghamshire HP20 2PJ

1 Roberts D. Dispensing doctors. BMF 1992;305:187. (18 July.)

2 Prescription Pricing Authority. Annual report 1990/91. Newcastle upon Tyne: PPA, 1991.

EDIToR,-David Roberts's riposte to Baroness Cumberlege's remarks in the House of Lords concerning dispensing doctors is unconvincing.' He argues that because dispensing doctors show lower average costs per prescribed item (less value added tax) than pharmacists, dispensing doctors have saved the government $£ 33 \mathrm{~m}$ over the six years 1985-91. He does not mention, however, how many items the dispensing doctors prescribed per patient.

The health services indicator dataset for $1989-90$ shows that dispensing doctors prescribe more items than their non-dispensing colleagues (8.51 items per patient compared with $7 \cdot 87)$. Thus the net ingredient cost per patient (excluding value added tax) for patients of dispensing doctors was $£ 42.58$, compared with $£ 42.11$ for patients of nondispensing doctors. This small but higher amount means that, rather than saving the government $£ 5.8 \mathrm{~m}$ in $1989-90$, dispensing doctors actually cost the government $£ 1.41 \mathrm{~m}$. Furthermore, this figure ignores additional costs such as fees and container allowances. This may help to explain Baroness Cumberlege's concern.

A J MORTON-JONES M A L PRINGLE

Department of General Practicc,

Queen's Medical Centre,

Nottingham NG7 2UH

1 Roberts D. Dispensing doctors. BMF 1992;305:187. (18 July.)

\section{Victims of Creutzfeldt-Jakob disease}

EDITOR,-Of course the 1900 or so families in the United Kingdom whose children received cadaveric pituitary derived human growth hormone that was contaminated with the agent of Creutzfeldt-Jakob dementia between 1959 and 1985 should have been informed seven years ago. Apart from the ethical considerations, the recipients should have been warned at the earliest opportunity never to be blood or tissue donors.

Many of the anxious families whose children were treated with human growth hormone before 1985 would have their anxieties alleviated if it were to be shown that they are constitutionally not susceptible to the agent of Creutzfeld-Jakob dementia. As Clare Dyer stated, there is no way of knowing how many recipients will eventually develop the disease. ${ }^{1}$ There is good evidence for believing, however, that only certain peoplethose of an unusual genotype-are likely to be susceptible to the disease after infection. The government is currently monitoring all the cases of Creutzfeldt-Jakob disease that occur in the United Kingdom as part of its surveillance of the effects, if any, of the outbreak of bovine spongiform encephalopathy on the human population. It would therefore be possible to establish which genotype is susceptible to the ailment, and those recipients of the contaminated human growth hormone who are of other genotypes could then be reassured. Even the susceptible individuals are not necessarily doomed: whether they develop the disease or not would also depend on the dose of the agent which they had received. This relatively simple matter is surely the least the government should be doing in these gloomy circumstances.

London NW3 4 XR

H C GRANT

1 Dyer C. Families of victims of Creutzfeldt-Jakob disease to sue government. $B M \mathcal{F}$ 1992;305:73-4. (11 July.)

\section{Emergency treatment against a patient's wishes}

EDITOR, - The issue of the right to refuse lifesaving treatment has been highlighted by two recent court cases: a 16 year old girl with anorexia nervosa was overruled in her decision to refuse being fed ${ }^{\prime}$ and the Court of Appeal decided that blood transfusions should be given to a 20 year old victim of an accident against her wishes. ${ }^{23}$ The delivery of emergency treatment against the apparent wishes of the patient may also pose a major dilemma for a doctor treating a casualty.

In a recent personal experience I was called, as medical registrar, to the casualty department to see a middle aged man who had attempted suicide by drug overdose one to two hours before. The patient suffered from ischaemic heart disease; there was no known psychiatric history, and the circumstances that had provoked him to take the overdose were unclear. It was thought that he had taken about 100 tablets, including atenolol, isosorbide, diltiazem, and temazepam. His blood pressure was $90 / 50 \mathrm{~mm} \mathrm{Hg}$, he had a slight bradycardia, and he was rather confused.

We decided that further deterioration could be averted only by gastric lavage. The patient refused and indicated forcefully that he wanted to die. There were no features of psychosis, and no section in the Mental Health Act applied. ${ }^{+}$Such a situation faces a doctor with the dilemma of either acquiescing in the patient's demands or treating against his or her wishes. Because of this patient's deteriorating physical condition an immediate decision was necessary. We undertook gastric lavage and removed a large proportion of the ingested tablets. The patient subsequently developed severe brady cardia and heart block and required cardiac pacing. Although he remained aggressive, no undue force was required. His mental state deteriorated, and he became semicoherent.

The treatment was not covered by the Mental Health Act, and the attending medical staff were protected only by the common law duty of care owed by a doctor to his or her patients and by the doctrine of necessity. ${ }^{56}$ Guidelines issued by the Department of Health state that "a patient has a fundamental right to grant or withhold consent prior to examination or treatment." The guidelines also, however, give examples of treatment that have raised concern and, in relation to maternity services, state that "decision may have to be taken swiftly at a time when the woman's ability to give consent is impaired, for example, as a result of medication including analgesia. If the safety of the woman or child is at stake, the obstetrician or midwife should take any reasonable action that is 
necessary." The decision in the House of Lords in one case states "In considering lawfulness of medical and surgical treatment given to a patien who for any reason, temporary or permanent, lacks the capacity to give or to communicate consent to treatment, it was stated to be axiomatic that treatment which is necessary to preserve life, health or well being of the patient may lawfully be given without consent."

In emergency treatment, where decisions need to be taken quickly, the legal position may be far from clear cut and medical staff may be open to prosecution for assault under common law. Mos medical staff have little or no appreciation of the lack of clarity in the legal position governing the treatment of patients against their wishes in emergencies. The case concerning the Jehovah's Witness raised "for the first time in English courts the question of whether an adult has the constitutional right to die."”

The patient described here made a complete recovery. Several weeks later he came to the outpatients department without an appointment to thank us profusely for having saved his life. The laws governing the treatment of drug overdose should be clarified to protect doctors who otherwise may face legal proceedings for acting in good faith and with compassion

DANIEL PECKHAM

Department of Respiratory Medicine,

City Hospital,

Nottingham NG5 IPB

1 Dyer C. 16 year old's refusal of treatment overrules. $B M$ 1992;305:76. (11 July.)

2 Gibb F. Appeal court asked to rule on women's right to die. Times 1992 July 23:16(col 1)

3 Dyer $C$. Court says doctors were right to treat Jehovah's Witness. BMF 1992;305:272. (1 August.)

4 Mental Health Act 1983. London: HMSO, 1983.

Kendell RE, Zealley AK. Companion to psychiatry studies. 4th ed. Edinburgh: Churchill Livingstone, 1988:665.

6 NHS Management Executive. A guide to consent for examination and treatment. London: Department of Health, 1990 ( $\mathrm{HC}(90) 22$.

$7 \mathrm{~F} v$ West Berkshire Health Authority (Mental Health Act Commission intervening) [1989] All ER54

\section{Mixed psychiatric wards}

EDIToR,-Alison Tonks reports on the sexual dangers confronting female patients in mixed psychiatric wards.' We have attempted to address this sensitive issue in our hospital.

Herzog Hospital serves a predominantly orthodox Jewish area in Jerusalem. When members of this subculture, which ordinarily observes a stric social separation of the sexes, are admitted to a mixed psychiatric ward the effect can compound the trauma that often accompanies admission especially if it is compulsory. Patients in a psychotic or manic state may occasionally conduct sexual relations while in a psychiatric ward. Pregnancy, abortion, and births have resulted. In our population female patients seem particularly prone to suffer profound remorse for such actions when their condition remits. In some cases husbands have refused to accept their wives back into the family.

One year ago we began to provide separate wards for many of our male and female patients. Since then a government commission established to study sexual assault and abuse in psychiatric wards has recommended that separate sex wards should be available for all patients requesting such an arrangement. $^{2}$ (One of us, IEA, was a member of the committee.) Predictably, this policy aroused the ire of many professional colleagues, who saw it as a regressive step in mental health care. But in our experience, which we are currently researching in greater detail, the policy has some beneficial effects: our patients seem satisfied with the change; a source of tension has been removed from the ward; no families have been broken up on account of extramarital sex; and patients who had hitherto been prevented by their families from being admitted are now coming to our emergency room seeking admission.

The crucial drive in past decades towards humanising psychiatric wards, which has contributed so much to patients' quality of life, has perhaps not been free of excesses. Clearly, mixed wards are beneficial for many mentally ill patients. For some acutely psychotic patients, however, mixed wards may have harmful consequences. In particular, patients from subcultures that maintain traditional separation of the sexes may be ill served by mixed wards. The hospital environment, as a component of treatment, must be adapted to the needs of individual patients.

ILYA E AVERBUCH

Psychiatric Department, PESACH LICHTENBERG

Herzog Hospital,

PO Box 140,

Jerusalem 91001 ,

Israel

1 Tonks A. Women patients vulnerable in mixed psychiatric wards. BMJ 1992;304:1331. (23 May.)

2 Shereshewsky B, et al. Final report of the investigation committee on protection of hospitalized mental patients against sexual assault and abuse. Jerusalem: Israel Ministry of Health, 1991.

\section{Medical reports for courts}

EDIToR,-I can but agree with J S Price that all medical reports that are to be used to help resolve a dispute should be requested by a neutral and objective body and not with the partisan overtones that are usually the case under the present medicolegal system.' Perhaps this topic should really be ventilated in the columns of legal rather than medical journals, or even be the subject of political negotiations, so that the climate of legislation is altered to achieve this more appropriate balance for such reports.

The problem is really a part of a much wider canvas on which English legal systems operate. So long as society deems it appropriate to use an adversarial system of resolving matters where objective proof is required, then for so long one side or the other will continue to attempt to outmanoeuvre its opponents. This system may encourage advocacy skills, but only too often it acts as an incentive for one side or the other to suppress inconvenient facts for its case and hope that the other side is not clever enough to unearth them. The dismal results of this procedural method include a tendency to miscarriage of justice (often appallingly serious, as many recent appeal cases in the English courts have shown) and suppression of truth. If J S Price's suggestion for supplying medical reports was implemented, it would be a move in the right direction for correcting these inconsistencies.

Birmingham B15 3TX

ANTHONY JOSEPH

1 Price JS. Medical reports for courts. BMf 1992;305:254. (25 July.)

\section{Poor Britain}

EDITOR,-I doubt whether many read the $B M \mathcal{F}$ from cover to cover, but the first sentence of the first editorial must be in a spotlight. Here Tony Delamothe states that "unemployment begets poverty, which begets ill health and premature death." If only it was this simple. In dispelling lingering doubts by citing the longitudinal study by the Office of Population Censuses and Surveys he shows that he is not fully conversant with that important research. Moser et al recognised the likely complexity of the associations between unemployment and health. Besides loss of income they suggested loss of social status, increased stress, and harmful behaviours induced by stress as other links. ${ }^{2}$ They also extended their analyses to test the possibility that the excess mortality among unemployed men might reflect simply their skewed social class distribution - it didn't.

We now also have evidence that the threat of loss of one's job can be a health hazard.$^{34}$ This influence is almost certainly independent of financial embarrassment; it can be detected years before redundancy. And, in any case, not all those made redundant will be impoverished. We have just seen a wave of white collar workers become unemployed in Britain. Some of these people were high earners and given generous severance packages. We must not allow the government to reinforce the view that unemployment can be harmful only because of lack of disposable income. This fallacy allows ministers to deflect criticism of present economic policy into the diffuse debate on what are the minimum benefit payments. It is then only a short and easy step to imply that the poor could be better off if they managed their money more carefully.

Health Centre,

Calne,

Wiltshire SN11 8NQ

1 Delamothe T. Poor Britain. BMF 1992;305:263-4. (1 August.)

2 Moser K, Fox J, Jones D. Unemployment and mortality in the OPCS longitudinal study. Lancet 1984;ii:1324-9.

3 Beale N, Nethercott S. Job loss and family morbidity: a study of a factory closure. $\mathcal{F} R$ Coll Gen Pract 1985;35:510-4.

4 Mattiasson I, Lindgärde F, Nilsson J $\AA$, Theorell T. Threat of unemployment and cardiovascular risk factors; longitudinal study of quality of sleep and serum cholesterol concentrations in men threatened with redundancy. BMF 1990;301:461-6.

\section{Disposal of used metered dose inhalers}

EDITOR,-Many patients with chronic respiratory disorders regularly use pressurised metered dose inhalers. The active drug in these inhalers is either dissolved or suspended in a liquid chlorofluorocarbon mixture in a sealed, pressurised container. There are no guidelines regarding disposal of used inhalers, although all the manufacturers warn that the canisters should not be burnt or punctured, even when empty. We asked 104 asthmatic patients how they disposed of used metered dose inhalers. Ninety six patients threw them in the waste bin, but four patients regularly burnt them and two buried them.

The use of chlorofluorocarbons in metered dose inhalers has been criticised owing to the possible damage to the ozone layer in the atmosphere.' Although the quantity of chlorofluorocarbons in the inhalers is small, certain countries have restricted the use of chlorofluorocarbons in medical aerosols. Many pharmaceuticals firms are trying to develop an alternative to chlorofluorocarbon propellants, and dry powder formulations are one such attempt. Until an alternative safe propellant is produced we need to remind patients regularly of safe methods of disposing of used inhalers. The pressurised canisters should not be burnt or punctured not only because of the danger of explosion but also because this releases remaining chlorofluorocarbons into the environment.

N P KEANEY

Royal Infirmary,

Sunderland SR2 7JE

1 The week in Nottingham: IT and CFCs. BMF 1992;305:192. (18 July.) 